MARCIN ORLICKI

https://doi.org/10.33995/wu2019.2.1

\title{
Rozkład obowiązków pomiędzy dystrybutorów w procesie zawierania umowy ubezpieczenia. Dokumentowanie realizacji obowiązków ustawowych związanych z dystrybucją ubezpieczeń
}

Artykuł określa kwestię dopuszczalności oraz ustala podstawowe zasady prowadzenia współpracy między dystrybutorami ubezpieczeń (brokerami ubezpieczeniowymi, agentami ubezpieczeniowymi oraz zakładami ubezpieczeniowymi] zgodnie z przepisami ustawy o dystrybucji ubezpieczeń. Wartykule wskazano również na konieczność i zasady prowadzenia przez dystrybutorów dokumentacji wykonywania obowiq̨zów zwiqzanych z dystrybucjq ubezpieczeń.

Słowa kluczowe: dystrybucja ubezpieczeń, dystrybutorzy ubezpieczeń, współpraca dystrybutorów, dokumentacja wykonania obowiązków dystrybucyjnych, konsorcjum brokerskie, pool koasekuracyjny.

\section{Uwagi wstępne}

Mimo że ustawa o dystrybucji ubezpieczeń ${ }^{1}$ weszła w życie w styczniu 2018 roku, wiele już napisano o sposobie interpretowania jej przepisów. Kwestie zasadnicze zostały poddane dogłębnej analizie. Nadszedł więc czas na podjęcie prób ustalenia wpływu nowych przepisów na szczególne, występujacce w praktyce życia gospodarczego sposoby wykonywania przez dystrybutorów ich obowiązków.

Niniejszy artykuł ma na celu dokonanie analizy prawnej przypadków dystrybucji ubezpieczeń wykonywanej przez współpracujących z sobą lub choćby przez działających obok siebie

1. Ustawa z dnia 15 grudnia 2017 r. o dystrybucji ubezpieczeń (tekst jedn. Dz. U. 2018, poz. 2210 z późn. zm.). 
dystrybutorów. Chodzi przede wszystkim o udzielenie odpowiedzi na pytanie o dopuszczalność nawiązania współpracy przez dystrybutorów ubezpieczeń w różnych konstelacjach personalnych oraz o podział obowiązków pomiędzy współpracujących dystrybutorów. Należy również odpowiedzieć na pytanie o możliwość umownego określania zasad współpracy między dystrybutorami oraz o prawną kwalifikację przypadków zaangażowania wielu dystrybutorów w czynności dystrybucyjne na podstawie wiążących zaleceń wydanych przez klienta lub ubezpieczyciela.

Obserwacja praktyki ubezpieczeniowej pokazuje, że zaangażowanie w dystrybucję dwóch lub większej liczby dystrybutorów zdarza się dość często. Takie ukształtowanie procedur dystrybucyjnych może przyczyniać się do redukcji kosztów albo też zapewniać większą efektywność dystrybucji na poszczególnych jej etapach (gdy każdy z dystrybutorów wykonuje czynności dystrybucyjne, w których jest wyspecjalizowany). Podział zadań między dystrybutorów może wynikać z woli ich mocodawców - ubezpieczycieli (gdy idzie o agentów ubezpieczeniowych) lub osób poszukujących ochrony ubezpieczeniowej (gdy chodzi o brokerów ubezpieczeniowych).

Skoro dystrybucja prowadzona przez wielu dystrybutorów ma sens ekonomiczny i jest zgodna z wolą stron umowy ubezpieczenia, należy określić prawne granice jej dopuszczalności oraz normy wskazujące, jak prowadzić taką działalność.

\section{Dystrybucja ubezpieczeń i dystrybutorzy ubezpieczeń}

Analiza dopuszczalności i zasad współpracy między dystrybutorami powinna rozpocząć się od dokonania ustaleń terminologicznych dotyczących dwóch fundamentalnych pojęć: dystrybucji ubezpieczeń oraz dystrybutora ubezpieczeń.

Zgodnie z art. 4 ust. 1 ustawy o dystrybucji ubezpieczeń, „dystrybucja ubezpieczeń oznacza działalność wykonywaną wyłącznie przez dystrybutora ubezpieczeń polegająca na:

1) doradzaniu, proponowaniu lub wykonywaniu innych czynności przygotowawczych zmierzajacych do zawarcia umów ubezpieczenia lub umów gwarancji ubezpieczeniowych;

2) zawieraniu umów ubezpieczenia lub umów gwarancji ubezpieczeniowych w imieniu zakładu ubezpieczeń, w imieniu lub na rzecz klienta albo bezpośrednio przez zakład ubezpieczeń;

3) udzielaniu pomocy przez pośrednika ubezpieczeniowego w administrowaniu umowami ubezpieczenia lub umowami gwarancji ubezpieczeniowych i ich wykonywaniu, także w sprawach o odszkodowanie lub świadczenie".

Dystrybucja ubezpieczeń obejmuje więc trzy obszary działań dystrybutorów ubezpieczeń:

- czynności faktyczne służące zawarciu umowy ubezpieczenia lub umowy gwarancji ubezpieczeniowej;

- czynności prawne polegające na zawieraniu umów ubezpieczenia bezpośrednio lub w imieniu, lub na rzecz innych podmiotów,

- czynności (zarówno faktyczne, jak i prawne) służące wykonywaniu i administrowaniu umowami ubezpieczenia lub umowami gwarancji ubezpieczeniowych.

Zgodnie z art. 3 ust. 1 pkt 8 ustawy o dystrybucji ubezpieczeń za dystrybutora ubezpieczeń należy uważać zakład ubezpieczeń, agenta ubezpieczeniowego, agenta oferującego ubezpieczenia uzupełniające lub brokera ubezpieczeniowego.

Aby mówić o współpracy między dystrybutorami ubezpieczeń przy zawieraniu lub wykonywaniu umowy ubezpieczenia, trzeba ustalić wcześniej, że współpracujące ze soba podmioty maja 
w danym przypadku status dystrybutora ubezpieczeń. Kwestia ta nie jest bynajmniej przesądzona treścią cytowanego wyżej art. 3 ust. 1 pkt 8 ustawy o dystrybucji ubezpieczeń, gdyż nie każdy z wymienionych tam podmiotów w każdym przypadku może być uznawany za dystrybutora.

Wydaje się, że w przypadku gdy umowa ubezpieczenia jest zawierana przy udziale pośrednika ubezpieczeniowego (agenta ubezpieczeniowego, agenta oferujacego ubezpieczenia uzupełniajace lub brokera ubezpieczeniowego), ubezpieczyciel nie może być traktowany jako dystrybutor. Art. 4 ust. 1 pkt 2 ustawy o dystrybucji ubezpieczeń stanowi bowiem, że dystrybutorem jest zakład ubezpieczeń w przypadku, gdy zawiera on umowę „bezpośrednio”. „Bezpośrednio”, czyli „bez pośrednika”2.

Zakład ubezpieczeń jest więc dystrybutorem ubezpieczeń tylko wówczas, gdy brak zaangażowania jakiegokolwiek innego pośrednika - brokera po stronie klienta lub agenta (albo też agenta oferujacego ubezpieczenia uzupełniajace] po stronie zakładu. Zakład ubezpieczeń jest w takim przypadku dystrybutorem „z konieczności”. Jego działania jako dystrybutora (polegające na realizacji obowiązków określonych w ustawie o dystrybucji ubezpieczeń) gwarantuja klientowi ochronę praw mimo braku pośrednika ${ }^{3}$.

Czynności faktyczne służące zawarciu umowy ubezpieczenia lub gwarancji oraz czynności prawne polegające na zawieraniu wspomnianych umów mogą być dokonywane przez dystrybutorów należących do każdego z typów, o których mowa w art. 3 ust. 1 pkt 8 ustawy o dystrybucji ubezpieczeń. Inaczej sprawa się ma z czynnościami służącymi wykonywaniu umów ubezpieczenia i gwarancji ubezpieczeniowych. Tego rodzaju czynności moga być uznane za dystrybucję ubezpieczeń wyłącznie wtedy, gdy podejmowane sa przez pośredników ubezpieczeniowych (czyli przez agentów ubezpieczeniowych, agentów oferujących ubezpieczenia uzupełniające, brokerów ubezpieczeniowych], nie zaś przez ubezpieczycieli.

Udzielanie pomocy w administrowaniu umowami ubezpieczenia lub umowami gwarancji ubezpieczeniowych i ich wykonywanie (także w sprawach o odszkodowanie lub świadczenie) przez inne podmioty niż pośrednicy ubezpieczeniowi jest oczywiście dopuszczalne. W takim przypadku jednak czynności te nie są uznawane za dystrybucję ubezpieczeń i nie stosuje się w odniesieniu do ich wykonywania (i do podmiotów je wykonujących) przepisów ustawy o dystrybucji ubezpieczeń.

Nie jest więc współpracą w wykonywaniu czynności dystrybucyjnych współdziałanie zakładów ubezpieczeń z pośrednikami ani też współdziałanie dwóch (lub więcej) zakładów ubezpieczeń służące wspólnemu wykonywaniu umów ubezpieczenia. Oznacza to, że nie mogą być uznawane za współpracę dystrybucyjna zakładów ubezpieczeń czynności, o których mowa w art. 4 ust. 10 ustawy o działalności ubezpieczeniowej i reasekuracyjnej ${ }^{4}$ (czyli takie jak: prowadzenie postępowań regresowych oraz postępowań windykacyjnych związanych z wykonywaniem umów ubezpieczenia

2. Tak słusznie twierdzi J. Pokrzywniak, [w:] Nowe zasady dystrybucji ubezpieczeń, [red.] J. Pokrzywniak, Wolters Kluwer, Warszawa 2018, s. 38. Autor wskazuje również na inne możliwe sposoby rozstrzygania problemu określania przypadków, w których zakład ubezpieczeń mógłby być traktowany jako dystrybutor ubezpieczeń.

3. Jak się zdaje, sensem wprowadzenia terminu dystrybucja ubezpieczeń w miejsce wcześniej powszechnie używanego pojęcia pośrednictwa ubezpieczeniowego jest właśnie objęcie nim działalności zakładów ubezpieczeń. Regulowanie przez ustawę działalności dystrybucyjnej zakładów ubezpieczeń jest potrzebne jednak tylko wówczas, gdy efektu ochrony klienta nie można osiaggnąć poprzez regulowanie działalności pośredników ubezpieczeniowych.

4. Ustawa z dnia 11 września 2015 r. o działalności ubezpieczeniowej i reasekuracyjnej (tekst jedn. Dz. U. 2018, poz. 999 z późn. zm.). 
i umów gwarancji ubezpieczeniowych, ustalanie przyczyn i okoliczności zdarzeń losowych, ustalanie wysokości szkód oraz rozmiaru odszkodowań oraz innych świadczeń należnych uprawnionym z umów ubezpieczenia lub umów gwarancji ubezpieczeniowych, wypłacanie odszkodowań i innych świadczeń należnych z tytułu umów ubezpieczenia i gwarancji ubezpieczeniowych, gdy ich wykonywania podejmuje się zakład ubezpieczeń na wniosek innego zakładu ubezpieczeń). Bez watpienia więc nie można uznać, że działalność ubezpieczycieli w ramach bezpośredniej likwidacji szkód z obowiązkowego ubezpieczenia odpowiedzialności cywilnej posiadaczy pojazdów mechanicznych ${ }^{5}$ jest objęta reżimem ustawy o dystrybucji ubezpieczeń.

\section{Współpraca brokerów ubezpieczeniowych}

Przy dokonywaniu czynności dystrybucyjnych na rzecz tego samego klienta i w odniesieniu do tego samego obszaru ochrony ubezpieczeniowej może działać więcej niż jeden broker ubezpieczeniowy.

Warunkiem koniecznym dla uznania, że dany broker wykonuje czynności na rzecz określonego klienta, jest udzielenie mu przez tegoż klienta zlecenia (którego elementem może być pełnomocnictwo do dokonania w imieniu klienta czynności prawnych). Jeśli klient posługuje się więcej niż jednym brokerem przy poszukiwaniu ochrony ubezpieczeniowej w danym obszarze, powinien precyzyjnie i rozłącznie rozdzielić między brokerami zakresy zlecenia i pełnomocnictwa ${ }^{6}$. Nie dotyczy to przypadku, gdy zaangażowani w obsługę danego klienta brokerzy zawarli między soba porozumienie określające zasady ich współpracy (konsorcjum brokerskie). W takim przypadku dopuszczalne jest zarówno łączne zlecenie lub umocowanie udzielone wszystkim uczestniczącym w konsorcjum brokerom do wykonywania wszystkich czynności dystrybucyjnych, jak i podział przez klienta czynności pomiędzy członków konsorcjum.

W istocie więc brokerzy obsługujący danego klienta działać moga „obok siebie” (czyli w zakresie zleconych im rozłącznych obszarów czynności dystrybucyjnych), jak i „wspólnie” (czyli w ramach wspólnego dla wszystkich zakresu czynności dystrybucyjnych). Działanie „wspólne” możliwe jest wyłącznie wówczas, gdy brokerzy zawarli między sobą porozumienie. Działanie „obok siebie” jest możliwe zarówno wtedy, gdy porozumienie takie zostało zawarte, jak i gdy do niego nie doszło.

5. Szerzej na temat bezpośredniej likwidacji szkód z obowiązkowego ubezpieczenia odpowiedzialności cywilnej posiadaczy pojazdów mechanicznych: E. Bagińska, Polski system bezpośredniej likwidacji szkód komunikacyjnych w świetle prawa ochrony konkurencji, „Wiadomości Ubezpieczeniowe” 2015, nr 3, s. 53-70; J. Orlicka, M. Orlicki, Kilka uwag o aspektach prawnych wprowadzania „bezpośredniej likwidacji szkód w Polsce”, [w:] Kompensacja szkód komunikacyjnych. Nowoczesne rozwiqzania ubezpieczeniowe / Traffic Accident Compensation Modern Insurance Solutions, [red.] K. Ludwichowska, Poltext, Warszawa 2011, s. 230; J. Orlicka, Bezpośrednia likwidacja szkód oparta na porozumieniu ubezpieczycieli - uwagi z perspektywy prawa konkurencji, „Prawo Asekuracyjne” 2014, nr 2, s. 55-67; M. Orlicki, Bezpośrednia likwidacja szkód po zawarciu przez ubezpieczycieli ogólnorynkowego porozumienia, „Prawo Asekuracyjne” 2015, nr 3, s. 3-16.

6. Przedmiotem niniejszego artykułu nie jest problem wielości zleceń lub pełnomocnictw udzielanych przez klienta wielu brokerom, w przypadku gdy zakres tych zleceń lub pełnomocnictw pokrywa się. Szerzej na ten temat: J. Nawracała, Cofnięcie pełnomocnictwa brokerskiego a prawo do kurtażu, „Prawo Asekuracyjne” 2012, nr 4, s. 34-48; J. Pokrzywniak, Rozliczenia pomiędzy brokerem ubezpieczeniowym a zakładem ubezpieczeń w świetle orzecznictwa sqdowego, w kontekście prac nad nowq ustawq o dystrybucji ubezpieczeń, „Prawo Asekuracyjne" 2017, nr 2, s. 58-66; S. Byczko, B. Kucharski, Obowiqzek lojalności mocodawcy wobec brokera ubezpieczeniowego, „Prawo Asekuracyjne” 2018, nr 4, s. 3-17. 
Porozumienie brokerów, którym klient zlecił wykonanie czynności dystrybucyjnych w różnych obszarach, powinno służyć lepszej ich koordynacji. Co oczywiste, nie można w nim zmieniać zakresu czynności, do których wykonania są zobowiązani poszczególni brokerzy. W tym zakresie decydująca jest wola klienta.

Brokerzy - uczestnicy konsorcjum, którym klient zlecił czynności dystrybucyjne w sposób łączny (bez wskazywania, który z brokerów wykonać ma poszczególne czynności), sami rozdzielają pomiędzy siebie czynności dystrybucyjne. Należy jednak pamiętać, że obowiązki o charakterze informacyjnym muszą być wykonane przez każdego z brokerów - ich celem jest bowiem zapewnienie klientowi pełnej i rzetelnej informacji dotyczącej tożsamości i statusu prawnego obsługującego go dystrybutora (art. 32 ust. 1 pkt 1-3, 5-8 oraz ust. 2 ustawy o dystrybucji ubezpieczeń]. Nie ma przeszkód, by obowiązki informacyjne odnoszące się do wszystkich członków konsorcjum wykonał w ich imieniu broker, który pełni rolę lidera konsorcjum.

Nie można skutecznie ustalić w porozumieniu zawartym przez brokerów, że obowiązki dotyczące przyjmowania i rozpatrywania reklamacji klientów (wynikające z przepisów art. 16 ust. 2 ustawy o dystrybucji ubezpieczeń oraz art. 3-10 ustawy o rozpatrywaniu reklamacji przez podmioty rynku finansowego i o Rzeczniku Finansowym?] będą wykonywane wyłącznie przez jednego lub niektórych członków konsorcjum brokerskiego. Obowiązki te obciążają każdego brokera wykonującego czynności dystrybucyjne, co oznacza, że klient może złożyć reklamację na ręce każdego z nich. Dopuszczalne jest jednak, by odpowiedź na reklamację złożoną danemu brokerowi została opracowana i przekazana klientowi przez innego brokera. Broker, który przekazuje odpowiedź klientowi, musi wszakże legitymować się stosownym upoważnieniem udzielonym przez brokera, któremu klient złożył reklamację.

\section{Współpraca brokera $z$ agentem}

Zarówno agenci, jak i brokerzy ubezpieczeniowi są pośrednikami ubezpieczeniowymi. Stojajednak po dwóch stronach barykady - agent działa na zlecenie ubezpieczyciela, broker działa dla poszukującego ochrony ubezpieczeniowej.

Wyraźne rozróżnienie ról agenta i brokera znalazło swój wyraz w przepisach ustawy o dystrybucji ubezpieczeń zakazujących pozostawania przez agentów i brokerów w relacjach, które zostały wyraźnie określone przez przepisy, jak również w innych relacjach, które mogłyby zagrażać wykonywaniu działalności w zakresie dystrybucji ubezpieczeń z zachowaniem wymogów uczciwości, rzetelności i profesjonalizmu oraz działania zgodnie z najlepiej pojętym interesem klientów [art. 25 i 30 ustawy o dystrybucji ubezpieczeń) ${ }^{8}$.

Fakt, że agent i broker mają zawsze różnych mocodawców i nie pozostają w żadnych trwałych relacjach, nie powoduje niemożności ich współdziałania przy wykonywaniu czynności dystrybucyjnych dotyczących tego samego klienta i tego samego zakresu ochrony ubezpieczeniowej.

7. Ustawa z dnia 5 sierpnia 2015 r. o rozpatrywaniu reklamacji przez podmioty rynku finansowego i o Rzeczniku Finansowym (tekst jedn. Dz. U. 2018, poz. 2038 z późn. zm.).

8. Szerzej na ten temat: M. Orlicki, Niedozwolone powiqzania między brokerami i agentami ubezpieczeniowymi, „Prawo Asekuracyjne” 2018, nr 2, s. 32-42. 
Jeśli przy zawieraniu tej samej umowy klient jest reprezentowany przez brokera, zaś ubezpieczyciel przez agenta, wówczas wykonywanie czynności dystrybucyjnych powinno zostać podzielone pomiędzy te podmioty. Wydaje się, że pierwszą zasadą tego podziału powinno być założenie, że czynność wyróżniająca działania brokera ubezpieczeniowego - udzielenie klientowi porady w oparciu o rzetelną analizę dostępnych na rynku produktów ubezpieczeniowych (art. 32 ust. 1 pkt. 4 ustawy o dystrybucji ubezpieczeń) - konsumuje obciażajacy każdego dystrybutora obowiązek dokonania analizy potrzeb i wymagań klienta (art. 8 ust. 1 ustawy o dystrybucji ubezpieczeń). Skoro klient poszukuje ochrony ubezpieczeniowej przy pomocy profesjonalnego reprezentanta, którym jest broker, agent jest zwolniony z wypełnienia obowiązku zapewnienia, by produkt ubezpieczeniowy odpowiadał potrzebom i wymaganiom tegoż klienta ${ }^{9}$.

Jeśli klient złoży wobec brokera pisemne oświadczenie o rezygnacji z uzyskania porady, rezygnuje tym samym z wszelkiej pomocy merytorycznej dystrybutorów ubezpieczeń służącej znalezieniu adekwatnego produktu ${ }^{10}$. Można więc stwierdzić, że w przypadku, gdy agent wie, że po stronie klienta działa broker ubezpieczeniowy, może uznać, że jest zwolniony z wykonywania obowiązków, o których mowa w art. 8 ust. 1 ustawy o dystrybucji ubezpieczeń. Nie ma przy tym znaczenia zakres udzielonego brokerowi pełnomocnictwa lub zlecenia ani też fakt rezygnacji z rekomendacji.

Również inne czynności dystrybucyjne, których celem jest ochrona interesów klienta, powinny być wykonywane przez brokera ubezpieczeniowego, nie zaś przez agenta. Rola agenta, który działa obok brokera przy dokonywaniu czynności dystrybucyjnych, ogranicza się do działań służących interesom ubezpieczyciela, do wykonywania obowiązków nałożonych przez prawo na ubezpieczyciela oraz do czynności technicznych i administracyjnych.

Nie można wykluczyć, że szczegółowy podział czynności dystrybucyjnych pomiędzy brokera i agenta zostanie ustalony w porozumieniu zawartym przez te podmioty. Porozumienie to nie powinno mieć charakteru stałego, lecz winno być zawierane ad hoc dla określenia zasad wykonywania czynności dystrybucyjnych odnoszących się do jednej umowy ubezpieczenia, jednego klienta lub co najwyżej grupy powiązanych ze sobą umów.

Co oczywiste, w przypadku dokonywania czynności dystrybucyjnych zarówno przez brokera, jak i przez agenta, każdy z tych podmiotów niezależnie od siebie musi wypełnić obowiązki informacyjne dotyczące ujawnienia tożsamości i statusu prawnego dystrybutora (art. 22 ust. 1 i 2 ustawy o dystrybucji ubezpieczeń - w odniesieniu do agenta ubezpieczeniowego, art. 32 ust. 1 pkt 1-3, 5-8 oraz ust. 2 ustawy o dystrybucji ubezpieczeń - w odniesieniu do brokera ubezpieczeniowego).

Brokerzy oraz multiagenci są zobowiązani do przyjmowania i rozpatrywania reklamacji, które zostały złożone na ich ręce. Za niedopuszczalne należy uznać w tym przypadku rozpatrywanie reklamacji przez brokera w imieniu multiagenta lub też przez multiagenta w imieniu brokera.

9. Należy zgodzić się z A. Tarasiuk i B. Wojno, którzy pisali: „Jakkolwiek ściśle literalne odczytywanie przepisu skutkowałoby obowiązkiem dystrybutora (lege non distinguente - każdego) do przeprowadzenia analizy wymagań i potrzeb, co oznaczałoby więcej niż jedną analizę, wykładnię taką należy odrzucić jako nieracjonalnạ. Nie ma żadnego uzasadnienia aksjologicznego, aby analiza była dokonywana podwójnie (wielokrotnie). Dylemat co do podmiotu obciążonego obowiązkiem analizy wymagań i potrzeb klienta należałoby, zdaniem autorów, rozstrzygnąć w ten sposób, że obowiązek ten spoczywa na dystrybutorze pozostającym w bezpośrednim kontakcie z klientem ( $w$ przypadku korzystania z usług brokera ubezpieczeniowego - dystrybutorem tym będzie zawsze broker]". Zob. A. Tarasiuk, B. Wojno, Analiza wymagań i potrzeb klienta w procesie dystrybucji ubezpieczeń, „Prawo Asekuracyjne” 2018, nr 3, s. 10.

10. Por. M. Orlicki, Analiza potrzeb klienta - rzeczywista czy pozorna?, „Prawo Asekuracyjne” 2019, nr 2, s. 26. 
Podstawą tego rodzaju współpracy w zakresie przyjmowania i rozpatrywania reklamacji musiałoby być bowiem zawarte przez te podmioty porozumienie kreujące „stały stosunek umowny” (które wszakże z mocy art. 30 ust. 3 pkt 2 ustawy o dystrybucji ubezpieczeń jest zakazane).

\section{Współpraca agentów ubezpieczeniowych}

Nie ma wạtpliwości co do tego, że dopuszczalne prawnie jest nawiązywanie i prowadzenie współpracy przez agentów ubezpieczeniowych przy wykonywaniu czynności dystrybucyjnych. Wspólne wykonywanie czynności agencyjnych oznacza podział czynności agencyjnych pomiędzy agentów w przypadku obsługi tego samego klienta. Co oczywiste, warunkiem wstępnym współpracy agentów ubezpieczeniowych jest ustalenie, że każdy z nich zawarł umowę agencyjną z danym ubezpieczycielem, a postanowienia każdej z umów agencyjnych pozwalają na reprezentowanie przez każdego z agentów danego ubezpieczyciela w odniesieniu do danego produktu ubezpieczeniowego.

We współpracę przy wykonywaniu czynności agencyjnych mogą być zaangażowani zarówno agenci wyłączni danego ubezpieczyciela, jak i multiagenci (i w układach jednolitych rodzajowo, i mieszanych). Nic nie stoi na przeszkodzie, by współpraca była podejmowana także pomiędzy agentami oferującymi ubezpieczenia uzupełniające, jak również między tymi podmiotami a agentami ubezpieczeniowymi.

Podział czynności dystrybucyjnych między agentów ubezpieczeniowych może nastapić:

- poprzez zawarcie stosownego porozumienia między agentami nawiązującymi współpracę,

- poprzez nałożenie przez zakład ubezpieczeniowy na każdego z agentów obowiązku wykonywania określonych czynności dystrybucyjnych w sposób skoordynowany z czynnościami, których obowiązek wykonywania został narzucony innemu agentowi danego ubezpieczyciela.

Nawet wówczas, gdy podstawą współpracy między agentami jest zawarte przez nich porozumienie, konieczne jest uzyskanie zgody ubezpieczyciela na taki sposób wykonywania czynności dystrybucyjnych. Zgoda taka może mieć charakter blankietowy i zawierać się w treści umowy agencyjnej. Jeśli jednak umowa agencyjna nie zawiera stosownych postanowień (lub też wyrażony został w jej treści wyraźny zakaz wykonywania przez agenta czynności dystrybucyjnych wspólnie z innymi podmiotami], wówczas niezbędne jest uzyskanie zgody ubezpieczyciela na zawarcie konkretnego porozumienia o współpracy między agentami.

Jeśli podmiotem określającym zasady współpracy miedzy agentami jest ubezpieczyciel, on sam przejmuje ciężar koordynowania dystrybucji prowadzonej przez wielu swoich agentów. Porozumienie między agentami nie jest w takim przypadku niezbędne, choć niekiedy jego zawarcie może okazać się użyteczne. Dotyczy ono jednak w tym przypadku raczej kwestii technicznych, w szczególności zasad komunikacji wewnętrznej między współpracującymi ze sobą agentami.

Współpracujący ze sobą agenci ubezpieczeniowi wykonują czynności dystrybucyjne w ramach przyjętego w porozumieniu lub narzuconego przez ubezpieczyciela podziału czynności. Każdy z nich musi jednak wykonać obowiązi informacyjne, o których mowa w art. 21 ustawy o dystrybucji ubezpieczeń (informacje dla klienta o tożsamości i charakterze wynagrodzenia agenta). Poza tym multiagenci są zobligowani do wykonywania obowiązków dotyczących przyjmowania i rozpatrywania reklamacji zgłaszanych przez klientów. 


\section{Współpraca zakładów ubezpieczeń}

Jak już stwierdzono wcześniej, udział jakiegokolwiek pośrednika ubezpieczeniowego w procedurze zawierania umowy ubezpieczenia powoduje, że zakład ubezpieczeń nie może być uznawany za dystrybutora ubezpieczeń. Umowa ubezpieczenia nie jest bowiem w takim przypadku zawierana bezpośrednio przez zakład, lecz pośrednio - przy udziale pośrednika, którego obciążaja obowiązki dystrybucyjne wobec klienta.

Jeżeli jednak umowa ubezpieczenia jest zawierana bezpośrednio przez dwa zakłady ubezpieczeń (lub kilka zakładów), wówczas wszystkie powinny być traktowane jako dystrybutorzy - wszystkie one zawierają umowę bezpośrednio.

W przypadku koasekuracji wszyscy zaangażowani ubezpieczyciele są stronami zawieranej umowy i wszyscy oni (przy braku zaangażowania pośrednika ubezpieczeniowego) powinni być uznawani za dystrybutorów ubezpieczeń. Czynności dystrybucyjne są bowiem dokonywane przez samych ubezpieczycieli lub na ich zlecenie przez lidera poolu koasekuracyjnego (lub też innego koasekuratora lub koasekuratorów, którym ze względu na ich szczególne doświadczenia i kompetencje dotyczące dystrybucji produktów ubezpieczeniowych określonego rodzaju zostanie powierzone wykonywanie czynności dystrybucyjnych w imieniu pozostałych koasekuratorów ${ }^{11}$.

Obowiązki informacyjne zakładu ubezpieczeń występującego w roli dystrybutora (określone w art. 23 ustawy o dystrybucji ubezpieczeń) obciążają każdego z koasekuratorów. To samo dotyczy obowiązków ubezpieczycieli związanych z przyjmowaniem i rozpatrywaniem reklamacji złożonych przez klientów.

\section{Dokumentowanie wykonania obowiazków dystrybucyjnych}

Ochrona własnych interesów wymaga od każdego ze współpracujących dystrybutorów udokumentowania zakresu przyjętych na siebie obowiązków oraz faktu ich właściwego wypełnienia.

W przypadku współpracy między brokerami oraz współpracy między agentami bezpieczniejszym rozwiązaniem jest ścisły i wyraźny podział obowiązków między dystrybutorów dokonany przez ich wspólnego mocodawcę niźli przyjęcie przez nich łącznie określonego zakresu obowiązków i wewnętrzny podział ich realizacji. Tylko bowiem w przypadku wyraźnego podziału obowiązków dystrybucyjnych każdy z dystrybutorów odpowiada wyłącznie za swe własne działania - w odniesieniu zarówno do wykonywania obowiązków dystrybucyjnych, jak i do dokumentowania sposobu podjętych działań. Gdy zaś dwóch lub kilku brokerów albo dwóch lub kilku agentów wykonuje wspólnie zadania, które nie zostały indywidualnie przypisane żadnemu z nich, zarówno ich prawidłowe wykonanie, jak i rzetelne udokumentowanie staje się zadaniem całego konsorcjum. Konieczne jest w takim przypadku stworzenie wewnętrznych mechanizmów koordynacji działań dystrybucyjnych oraz prowadzenia i przechowywania ich dokumentacji.

Należy pamiętać, że dokumentowanie wykonania obowiązków dystrybucyjnych służy temu, by w razie kontroli prowadzonej przez organ nadzoru lub w przypadku sporu cywilnego dystrybutor

11. Szeroko o koasekuracji: J. Orlicka, Cywilnoprawne i antymonopolowe aspekty koasekuracji, „Prawo Asekuracyjne" 2007, nr 4, s. 65-79. 
mógł posłużyć się dowodami na rzeczywiste i prawidłowe merytorycznie wypełnienie tych obowiązków. W szczególności wypełnienie najistotniejszego z obowiązków dystrybucyjnych - dokonania prawidłowej analizy wymagań i potrzeb - musi być udokumentowane poprzez utrwalenie poszczególnych etapów jego realizacji: zadawania pytań, uzyskiwania od klienta odpowiedzi, analizy ich treści, przedstawienia produktów ubezpieczeniowych użytecznych dla klienta oraz wyboru przez klienta jednego z tych produktów. Gdy dystrybutorem jest broker ubezpieczeniowy, dokumentacja musi odnosić się do podstaw, na których broker zbudować mógł swą rekomendację oraz jej treść.

W każdym przypadku (zarówno gdy chodzi o ubezpieczyciela, jak i o agenta oraz brokera) niezwykle ważne jest udokumentowanie treści zadanych klientowi pytań i treści udzielonych przez niego odpowiedzi. Analiza potrzeb i wymagań klienta opiera się bowiem zawsze na „uzyskanych od klienta informacjach". Uzyskanie informacji (zadanie pytań) ma być profesjonalne, zaś uzyskane odpowiedzi - prawdziwe. Niewłaściwe pytania lub nieprawdziwe odpowiedzi determinuja wadliwość całej analizy potrzeb i wymagań, a wskutek tego - całego procesu dystrybucyjnego.

Jeśli zaś klient odmawia odpowiedzi na pytania lub dokonuje bezpośredniego wyboru konkretnego produktu ubezpieczeniowego, obowiazkiem dystrybutora jest udokumentowanie woli klienta.

Od rzetelnego dokumentowania wypełnienia obowiązków dystrybucyjnych zależy możliwość skutecznego dochodzenia przez klientów roszczeń wobec dystrybutorów oraz podmiotów, które ponoszą odpowiedzialność za działania dystrybutorów (ubezpieczycieli, którzy zawarli umowy agencyjne z agentami wyłącznymi, oraz ubezpieczycieli odpowiedzialności cywilnej multiagentów oraz brokerów ubezpieczeniowych]. Niewykluczone, że za kilka lat istotnym czynnikiem kształtowania wysokości prowizji dla agentów wyłącznych oraz ustalania wysokości składek w obowiązkowych ubezpieczeniach OC multiagentów i brokerów ubezpieczeniowych będzie ocena rzetelności dokumentacji wykonywania czynności dystrybucyjnych przez danego pośrednika.

\section{Podsumowanie}

Współdziałanie dystrybutorów ubezpieczeń służy podniesieniu jakości obsługi klienta i jako takie godne jest akceptacji i wsparcia. Jest ono możliwe nawet wówczas, gdy dystrybutorzy ci reprezentują interesy innych podmiotów. W istocie bowiem celem działania każdego z nich jest zapewnienie klientowi użytecznego dla niego ubezpieczenia i wykonanie umowy w sposób zgodny z jej treścią. W praktyce działania rzetelnych profesjonalistów upodabniają się do siebie bez względu na to, kto jest ich mocodawca.

Najbliższe lata będą zapewne czasem intensywnego kształtowania się struktur gospodarczych i prawnych służących wykonywaniu czynności dystrybucyjnych oraz okresem, w którym skrystalizują się nowe zwyczaje rynkowe w tym obszarze. Bardzo ważne jest, by prawo nie hamowało efektywności, innowacji i kreatywności uczestników rynku, a zakazywało współdziałania wyłącznie wówczas, gdy zagrożone lub naruszone są żywotne interesy klientów.

Czynnikiem hamującym rozwój złożonych struktur dystrybucyjnych jest obecnie niepewność co do sposobu oceny działania takich struktur przez sądy i organ nadzoru. Niepokój dystrybutorów wzbudza w szczególności surowo zarysowany w ustawie o dystrybucji ubezpieczeń zakaz powiązań między agentami i brokerami ubezpieczeniowymi.

Czas pokaże, na ile koordynacja działań dystrybutorów zyska przychylność organu nadzoru i sądów. Zapewne cennym drogowskazem byłoby wydanie przez organ nadzoru rekomendacji 
określających granice i zasady dozwolonej współpracy dystrybutorów w tych jej obszarach, które mogą budzić wạtpliwości prawne.

\section{Wykaz źródeł}

Bagińska E., Polski system bezpośredniej likwidacji szkód komunikacyjnych w świetle prawa ochrony konkurencji, „Wiadomości Ubezpieczeniowe” 2015, nr 3.

Byczko S., Kucharski B., Obowiqzek lojalności mocodawcy wobec brokera ubezpieczeniowego, „Prawo Asekuracyjne” 2018, nr 4.

Nawracała J., Cofnięcie pełnomocnictwa brokerskiego a prawo do kurtażu, „Prawo Asekuracyjne” 2012, $\mathrm{nr} 4$.

Orlicka J., Bezpośrednia likwidacja szkód oparta na porozumieniu ubezpieczycieli - uwagi z perspektywy prawa konkurencji, „Prawo Asekuracyjne” 2014, nr 2.

Orlicka J., Cywilnoprawne i antymonopolowe aspekty koasekuracji, „Prawo Asekuracyjne” 200?, nr 4.

Orlicka J., Orlicki M., Kilka uwag o aspektach prawnych wprowadzania „bezpośredniej likwidacji szkód w Polsce", [w:] Kompensacja szkód komunikacyjnych. Nowoczesne rozwiq̨ania ubezpieczeniowe / Traffic Accident Compensation Modern Insurance Solutions, Ludwichowska K. [red.], Poltext, Warszawa 2011.

Orlicki M., Analiza potrzeb klienta - rzeczywista czy pozorna?, „Prawo Asekuracyjne” 2019, nr 2.

Orlicki M., Bezpośrednia likwidacja szkód po zawarciu przez ubezpieczycieli ogólnorynkowego porozumienia, „Prawo Asekuracyjne” 2015, nr 3.

Orlicki M., Niedozwolone powiqzania między brokerami i agentami ubezpieczeniowymi, „Prawo Asekuracyjne" 2018, nr 2.

Pokrzywniak J., Rozliczenia pomiędzy brokerem ubezpieczeniowym a zakładem ubezpieczeń w świetle orzecznictwa sqdowego, w kontekście prac nad nowq ustawq o dystrybucji ubezpieczeń, „Prawo Asekuracyjne” 2017, nr 2.

Tarasiuk A., Wojno B., Analiza wymagań i potrzeb klienta w procesie dystrybucji ubezpieczeń, „Prawo Asekuracyjne” 2018, nr 3.

\section{Division of duties among distributors during the process of concluding an insurance contract. Documenting the fulfillment of statutory obligations related to insurance distribution}

The article describes the issue of admissibility of cooperation between insurance distributors (insurance brokers, insurance agents and insurance companies] and sets out the basic principles thereof in accordance with the provisions of the Polish Insurance Distribution Act. The author of the article also points out the necessity and principles of keeping documentation by distributors to perform duties related to insurance distribution. 
Rozkład obowiązków pomiędzy dystrybutorów w procesie zawierania umowy ubezpieczenia...

Key words: insurance distribution, insurance distributors, cooperation of distributors, documentation of distribution obligations, brokerage consortium, co-insurance pool.

DR HAB. PROF. UAM MARCIN ORLICKI - radca prawny, specjalista w zakresie prawa cywilnego i prawa ubezpieczeniowego, Uniwersytet im. Adama Mickiewicza, Wydział Prawa i Administracji, Katedra Prawa Cywilnego, Handlowego i Ubezpieczeniowego, członek kolegium redakcyjnego „Prawa Asekuracyjnego" oraz rad nadzorczych spółek grupy GENERALI w Polsce.

e-mail: orlicki@amu.edu.pl

https://orcid.org/0000-0001-8396-9439 
